\title{
PERLINDUNGAN SAKSI PIDANA MENURUT HUKUM PIDANA INDONESIA DAN HUKUM PIDANA ISLAM
}

\author{
Adam Sani \\ Fakutas Ilmu Sosial dan Ilmu Politik, Universitas Teuku Umar \\ E-mail: Adam_beutong87@yahoo.com
}

\begin{abstract}
The purpose of research and study to find out and explain the concept of witness protection in criminal cases under Indonesian criminal law and the criminal law of Islam and to explain the concept of comparative analysis on the protection of witnesses in criminal cases in the criminal law Indonesia.Penelitian this method of normative legal research, the study in the form of legislation, legal principles, norms, and others. In the discussion of this thesis is done through a comparative descriptive approach (comparison), which describe and analyze data on the protection of witnesses, according to the conception of Indonesian criminal law and criminal law of Islam. The results showed that first, the concept of witness protection in the Indonesian criminal law and the criminal law of Islam has much in common they both protect the witnesses have efforts to comply with the provision of security to the witness so that in spite of the threats of others both a threat to life, honor, finances and family. But what sets it apart is the legal basis, terms and various witnesses, the agency that protects witnesses and witness protection. Suggested to the parties that have the authority to order the witness protection sincere and serious in protecting witnesses in accordance with what is stipulated in the regulations.
\end{abstract}

Keywords; witness protection, criminal law of Indonesia, Islamic law 


\section{PENDAHULUAN}

Salah satu alat bukti yang sah dalam proses peradilan pidana adalah keterangan saksi dan/atau korban yang mendengar, melihat atau mengalami sendiri terjadinya suatu tindak pidana dalam upaya mencaridan menemukan kejelasan tentang tindak pidana yang dilakukan oleh pelaku tindak pidana. Penegak hukum dalam mencari dan menemukan kejelasan tentang tindak pidana yang dilakukan oleh pelaku tindak pidana sering mengalami kesulitan karena tidak dapat menghadirkan saksi disebabkan adanya ancaman baik fisik maupun psikis dari pihak tertentu (Yahya Harahap, 2009).

Kedudukan saksi dan keterangan saksi diposisikan diurutan pertama dibandingkan dengan alat bukti lainnya. Urutan ini merujuk pada alat bukti yangpertama kali diperiksa dalam tahap pembuktian di persidangan. Banyak sekali kasus yang tidak terungkap dan tidak terselesaikan, hal ini disebabkan oleh saksi dan korban takut memberikan keterangan karena mendapatkan ancaman dari pihak tertentu.Jaminan perlindungan terhadap saksi sangat penting mengingat peranan saksi yang sangat urgen dalam memutuskan perkara, maka seharusnya perlindungan itu tidak saja berupa perlindungan perkara dan pribadi semata dan bukan juga berupa perlindungan secara fisik dan mental dari ancaman, gangguan, teror, dan tindak kekerasan, tetapi juga berupa jaminan kesejahteraan untuk saksi berupa jaminan kehidupan.

Bahagian dari konsep perlindungan terhadap saksi pemerintah Indonesia telah mengeluarkan UU RI No.13 Tahun 2006 tentang Perlindungan Saksi dan Korban. Undangundang No. 13 Tahun 2006, Pasal 1, menegaskan bahwa;"saksi merupakan orang yang dapat memberikan keterangan guna kepentingan penyidikan, penuntutan, dan pemeriksaan di sidang pengadilan tentang suatu perkara pidana yang ia dengar sendiri, ia lihat sendiri dan/atau ia alami sendiri.Keberadaan LPSK bagian untuk memberikan perlindungan hukum dan keamanan yang memadai kepada saksi dan korban, sehingga ia tidak merasa terancam dan intimidasi baik hak maupun jiwanya. Dalam Pasal 3 Undang-Undang No. 13 Tahun 2006 menegaskan bahwa perlindungan saksi dan korban berasaskan pada penghargaan atas harkat dan martabat manusia, rasa aman, keadilan, tidak diskriminatif dan kepastian hukum. Perlindungan disini bertujuan memberikan rasa aman kepada saksi dalam memberikan keterangan dalam setiap proses peradilan, saksi tidak perlu takut lagi untuk melapor ataupun memberikan.

Disisi lain, ditinjau dari sistim hukum Islam mengenai perlindungan saksi juga memiliki aturan yang jelas baik terdapat dalam al-Qur'an, al-Hadits maupun pendapat para ulama, karena agama merupakan wadah yang tertinggi nilainya dalam usaha memerangi kejahatan. Agama bertujuan untuk mencapai kebaikan penganutnya dan secara otomatis harus melawan kejahatan. Dengan kesadaran tinggi terhadap agama seseorang tidak akan berbuat kejahatan. Dalam sumber utama hukum Islam, yakni al-Qur'an ditegaskan pula bahwa keberadaan seorang saksi sangat memiliki peranan penting untuk mengungkapkan sebuah kebenaran. Bahkan seorang saksi diharapkan bersikap adil dalam memberikan informasi dan dilarangkeras untuk memberikan keterangan palsu dalam mengungkap sebuah fakta.

Sebagaimana terdapat dalam Al-Qur'an surat Al-Maidah ayat 8: yang artinya:

Hai orang-orang yang beriman hendaklah kamu Jadi orang-orang yang selalu menegakkan (kebenaran) karena Allah, menjadi saksi dengan adil. Dan janganlah sekali-kali kebencianmu terhadap sesuatu kaum, mendorong kamu untuk berlakutidak adil. Berlaku adillah, karena adil itu lebih dekat kepada takwa. Dan bertakwalah kepada Allah, Sesungguhnya Allah Maha mengetahui apa yang kamu kerjakan. (QS. Al-Maidah : 8)

Kesaksian itu fardhu 'ain bagi orang yang memikulnya, bila dia dipanggil untuk itu dan dikhawatirkan kebenarannya akan hilang, bahkan wajib apabila dikhawatirkan lenyapnya kebenaran meskipun dia tidak dipanggil untuk itu. Kesaksian itu wajib ditunaikan apabila saksi mampu menunaikannya tanpa adanya bahaya yang menimpanya baik di badannya, kehormatannya, hartanya ataupun keluarganya, karena apabila saksi itu mendapat kesulitan baik berupa ancaman kepada keluarga, kehormatan, harta dan jiwanya maka saksi tersebut akan 
memberikan keterangan sesuai dengan apa yang diinginkan oleh pengancam. Untuk menghindari hal tersebut dan demi untuk menegakkan keadilan, maka saksi mendapatkan perlindungan. Menurut hukum Islam perlindungan itu terbagi atas perlindungan terhadap agama, akal, jiwa, kehormatan, dan harta. Islam juga mempunyai hak asasi yangmenurut Abu al-A'la al-Maududiy, hak-hak asasi seorang muslim adalah sebagaiberikut: hak untuk hidup, hak atas keselamatan hidup, penghormatan terhadapkesucian wanita, hak untuk memperoleh kebutuhan pokok, hak individu ataskebebasan, hak atas keadilan, persamaan derajat umat manusia, hak untukkerjasama dan tidak bekerja sama (Maulana Abu A'la, 1995).

\section{Saksi Menurut Hukum Pidana Indonesia}

Menurut bahasa, Saksi adalah sebuah kata benda dalam bahasa Indonesia yang berarti "orang yang melihat atau mengetahui" (Andi Hamzah, 1986). Saksi merupakan seorang manusia belaka atau manusia biasa, ia dapat dengan sengaja bohong, dan dapat juga jujur menceritakan suatu hal tertentu. Seseorang saksi harus menceritakan hal yang sudah lampau, dan tergantung dari daya ingat dari orang perseorang, apa itu dapat dipercaya atas kebenarannya(Wirjono, 2003).Saksi adalah orang yang dapat memberikan keterangan guna kepentingan penyelidikan, penyidikan, penuntutan dan/atau pemeriksaan disidang pengadilan tentang perkara pelanggaran HAM yang berat yang ia dengar sendiri, lihat sendiri, dan alami sendiri yang memerlukan perlindungan fisik dan mental dari ancaman, gangguan, teror dan kekerasan dari pihak manapun (Wirjono, 2003).

Pengertian saksi dalam bahasa hukum adalah orang yang menyaksikan sendiri suatu kejadian, orang yang memberi penjelasan di dalam sidang pengadilan untuk kepentingan semua pihak yang dapat memberikan keterangan tentang segala sesuatu yang didengar, dilihat dan dialami sendiri untuk kepentingan penyidikan, penuntutan dan peradilan mengenai suatu perkara (Sudarsono, 2007). Sedangkan yang dimaksud dengan keterangan saksi adalah suatu alat bukti dalam perkara pidana yang berupa keterangan dari saksi mengenai suatu peristiwa pidana yang ia dengar sendiri dan ia alami sendiri dengan menyebutkan alasan dari perbuatannya itu.Berdasarkan Undang-undang RI No. 13 tahun 2006 Tentang Perlindungan Saksi dan Korban menerangkan bahwa, saksi adalah orang yang dapat memberikan keterangan guna kepentingan penyelidikan, penyidikan, penuntutan dan pemeriksaan di sidang pengadilan tentang suatu perkara pidana yang ia dengar sendiri, ia lihat sendiri, dan/atau ia alami sendiri.

Dalam penyelesaian kasus-kasus pidana, saksi memiliki peranan yangsangat penting mengingat saksi memiliki peranan dalam memberikan informasi yang lengkap guna memperkuat dakwaan. Keterangan yang diberikan oleh saksi akan sangat membantu penyidikan untuk mengungkap peristiwa pidana.

Lembaga Perlindungan Saksi Dan Korban (LPSK) dibentuk berdasarkan UU Nomor 13 Tahun 2006 tentang Perlindungan Saksi dan Korban. Lahirnya Undang- Undang Perlindungan Saksi dan Korban datang bukan dari aparat hukum, polisi, jaksa, ataupun pengadilan akan tetapi datang dari inisiatif kelompok masyarakat yang memiliki pandangan bahwa saksi dan korban sudah saatnya diberikan perlindungan dalam sistem peradilan pidana.LPSK dibentuk pada tanggal 8 Agustus 2008, disebutkan pula bahwa LPSK adalah Lembaga yang bertugas dan berwenang untuk memberikan perlindungan dan hak-hak lain kepada Saksi dan Korban sebagaimana diatur dalam Undang-undang. Ruang lingkup perlindungan ini adalah pada semua tahap proses peradilan pidana. Tujuan undang-undang ini adalah untuk memberikan rasa aman kepada Saksi dan Korban dalam memberikan keterangan dalam proses peradilan pidana.Kedudukan dan fungsi LPSK adalah sebagai lembaga yang memberikan dan menjamin keamanan, kenyamanan terhadap Saksi dan Korban dalam memberikan keterangan yang dapat menjadi alat bukti pasca perkara belum diputuskan oleh hakim. 


\section{Saksi Menurut Hukum Pidana Islam}

Kesaksian ( شهادة ) itu diambil dari kata ( المشاهدة ) yang artinya melihat dengan mata kepala, karena syahid (orang yang menyaksikan) itu memberitahukan tentang apa yang disaksikan dan dilihatnya. Maknanya ialah pemberitahuan seseorang tentang apa yang ia ketahui dengan lafaz:aku menyaksikan atau aku telah menyaksikan (أشهاوشهدت) (Sayid Sabiq, 1987). Kesaksian berarti berita pasti. Musyahadah artinya sesuatu yang nyata, karena saksi adalah orang yang menyaksikan sesuatu yang orang lain tidak mengetahuinya. Dikatakan juga bahwa kesaksian berarti seseorang yang memberitahukan secara benar atas apa yang dilihat dan didengarnya (Uwaidah, 2007).

Kesaksian adalah menyampaikan perkara yang sebenarnya untuk membuktikan sebuah kebenarandengan mengucapkan lafaz-lafaz kesaksian di hadapan sidang pengadilan, seperti mendengar, melihat. Oleh karena itu untuk menyampaikan kesaksian dinamakan dengan memberi sebuah kesaksian (Ahmad ad-Daur, 2002). Saksi yang bisa didengar kesaksiannya adalah saksi yang benar-benar mengetahui, melihat, dan mendengar peristiwa pidana tersebut. Saksi haruslah benar-benar melihat, mendengar, mengetahui atau mengalami sendiri terhadap apa yang disaksikannya (ratio sciendi, 'ain al-yaqin), bukan berdasarkan cerita dari mulut kemulut atau dari pendengaran ke pendengaran. Lalu saksi menyusun atau mengambil kesimpulannya atau memberikan penilaiannya sendiri (ratio concludendi) (Roihan A Rasyid, 2006). Adapun syarat-syarat saksi yang bisa di dengar keterangannya adalah:

a. Mukallaf, yaitu sudah balig, maka tidaklah sah atau diterima saksi anak kecil, karena belum berakal (Mas'ud \& Zainal Abidin, 1999).

b. Beragama Islam, kesaksian untuk membela yang hak, orang kafir yang hendak membela hak orang Islam sebagai saksi dapat pula diterima. Adapun jika dalam keadaan darurat dan diperlukan, maka boleh kesaksian orang kafir terhadap muslim dan diantaranya yaitu kesaksian tentang wasiat dalam bepergian. dibolehkannya disini adalah dalam keadaan darurat karena dalam bepergian yang tidak didapatkan saksi dari orang Islam (Madkur, 1993). Mengenai masalah kesaksian non muslim baik berupa keterangan saksi maupun akta outentik dapat di terima sebagai alat bukti dalam persidangan majlis hakim pengadilan agama sepanjang menyangkut peristiwa atau kejadian memperjelas duduk atau guna memperjelas kejadian yang dipersengketakan oleh para pihak yang berperkara, bukan masalah yang berhubungan dengan ketentuan syari'at agama seperti masalah nikah, talaq, dan rujuk (Ansharuddin, 2004). Menurut Quraish Shihab dalam Tafsir alMisbah menjelaskan bahwasanya dua orang saksi laki-laki merupakan beragama Islam, dengan demikian syarat keharusan beragama Islam sangat penting terhadap suatu kesaksian karena nilai-nilai agama dapat mempengaruhi tinggi rendahnya moral seseorang (Qurais Shihab, 2000).

c. Merdeka, Tidaklah dapat diterima saksi orang yang masih hamba. Hal ini karena saksi adalah orang yang diserahi tanggung jawab, sedang budak tidak dapat bertanggung jawab sama sekali karena masih di bawah perintah tuannya.

d. Mempunyai sifat iffah, Artinya orang yang pandai menjaga kehormatan diri menurut martabat dan kedudukan. Orang-orang yang tidak pandai menjaga kehormatan diri, maka tidak sah dijadikan saksi karena tidak tahu malu (Mas’ud \& Zainal Abidin, 1999).

e. Adil, sifat keadilan ini merupakan tambahan bagi sifat Islam dan harus dipenuhi oleh para saksi yaitu kebaikan mereka harus mengalahkan keburukannya, serta tidak dikenal kebiasaan berdusta dari mereka (Sayid Sabiq, 1987).

f. Dapat berbicara, Sudah tentu seorang saksi harus dapat berbicara. Apabila dia bisu dan tidak sanggup berbicara, maka kesaksiannya tidak diterima, sekalipun dia dapat mengungkapkan dengan isyarat dan isyaratnya dapat dipahami, kecuali bila dia menulis kesaksiannya itu dengan tulisan. Demikian pendapat Abu Hanifah (Sayid Sabiq, 1987). 
g. Jangan ada tuhmah terhadap dirinya, Artinya ada prasangka yang tidak baik terhadap orang yang menjadi saksi, misalnya saja, ia akan diberi uang kalau mau jadi saksi. Orangorang yang demikian mungkin menjadi saksi dusta karena yang terlihat olehnya ialah keuntungan kepada dirinya, bukan kebenaran yang harus ditegakkan (Sayid Sabiq, 1987).

h. Janganlah saksi itu orang yang bermusuhan dengan tergugat (Sayid Sabiq, 1987).

Setiap orang dapat bertindak sebagai saksi. Namun ada segolongan orang yang dianggap tidak mampu menurut hukum. Golongan orang yang dianggap tidak mampu menurut hukum terdiri dari 2 macam, ada yang bersifat mutlak dan yang bersifat nisbi. Mereka yang dianggap tidak mampu secara mutlak adalah keluarga sedarah dan keluarga semenda menurut keturunan yang lurus dari salah satu pihak (Gemala Dewi, 2005). Sedangkan yang dianggap tidak mampu secara nisbi (relatif) adalah anak-anak yang belum mencapai umur 15 tahun dan orang gila, meskipun kadang-kadang ingatannya terang atau sehat. Dalam hal ini mereka boleh didengar keterangannya akan tetapi tidak sebagai saksi melainkan hanya sebagai penjelas (Gemala Dewi, 2005).

Lembaga perlindungan saksi dan korban dalam Islam masuk ke dalam wilayah al-hisbah. Artinya hisbah sendiri ialah menyuruh kepada kebaikan jika terbukti kebaikan ditinggalkan (tidak diamalkan) dan melarang dari kemungkaran jika terbukti kemungkaran dikerjakan, atau merupakan kewenangan menjalankan amar ma'ruf ketika yang ma'ruf mulai ditinggalkan orang danmencegah kemungkaran ketika yang munkar mulai dikerjakan orang secara nyata (Imam alMawardi, 2006).

Tujuan perlindungan saksi menurut hukum pidan Islamtidak terlepas dari tujuan hidup manusia itu sendiri, yaitu mengabdi kepada Allah. Hukum bagi agama Islam berfungsi mengatur kehidupan manusia, baik pribadi maupun hubungan masyarakat yang sesuai dengan kehendak Allah, untuk kebahagiaan hidup manusia di dunia dan akhirat.Dalam hukum Islam, martabat dan hak hidup manusia serta hak-hak yang melekat padanya telah mendapatkan perhatian yang maksimal. Manusia memiliki hak al-karamah (hak pemuliaan) dan hak alfadhilah (pengutamaan manusia). Apalagi misi Rasulullah SAW adalah rahmatan lil 'alamin, dimana keselamatan atau kesejahteraan merupakan tawaran untuk manusia dan alam (Ramli Atmasasta, 1997). Elaborasi (pengejawantahan) misi atau tujuan Islam di atas disebut al-khams atau lima prinsip dasar agama yang juga konsep yang digunakan dalam pelaksanaan perlindungan saksi yaitu:

a. Hifzud-din yaitu memberikan jaminan kepada umat Islam untuk memelihara agama dan keyakinannya (al-din). Sementara itu Islam juga menjamin sepenuhnya atas identitas (kelompok) agama yang bersifat lintas etnis. Oleh karena itu, Islam menjamin kebebasan beragama, dan larangan adanya pemaksaan agama yang satu dengan yang lain.

b. Hifzun-nafs yaitu menjamin hak atas jiwa (nyawa) manusia, untuk tumbuh dan berkembang secara layak. Dalam hal ini Islam menuntut adanya keadilan, pemenuhan kebutuhan dasar (hak atas penghidupan) pekerjaan, hak kemerdekaan dan keselamatan, bebas dari penganiayaan dan kesewenang-wenangan.

c. Hifzul-aql yaitu adanya suatu jaminan atas kebebasan berkreasi, kebebasan membar, kebebasan mengeluarkan opini, melakukan penelitian dan berbagai aktivitas ilmiah. Dalam hal ini Islam melarang terjadinya perusakan akal dalam bentuk penyiksaan, penggunaan obat-obatan terlarang, minuman keras dan lain-lain.

d. Hifzun-nasl yaitu merupakan jaminan atas kehidupan privasi setiap individu, perlindungan atas profesi (pekerjaan) jaminan masa depan keturunan dan generasi penerus yang lebih baik dan berkualitas.

e. Hifzun-mal yaitu dimaksudkan sebagai jaminan atas pemilikan harta benda, properti dan lainlain. Dan larangan adanya tindakan mengambil hak dari harta orang lain, seperti mencuri, korupsi, monopoli, dan lain-lain. 
Kesaksian dalam setiap kasus pidana Islam menepati urutan kedua setelah pengakuan. Keadaan seorang saksipun dalam hukum Islam sangat dilindungi dari ancaman-ancaman yang memberatkannya untuk memberikan ketrangan dalam sebuah proses pengadilan baik ancaman dari pelaku pidana maupun dari pihak lain. Untuk mengungkap suatu kasus pidana maka keberadaan seorang saksi sangat penting. Karena, tanpa adanya seorang saksi maka laporan bisa saja dibatalkan. Islam sangat melindungi hak-hak kebebasan hidup seseorang.

Perlindungan saksi dalam Islam mutlak harus dijaminkarena biasanya seseorang yang mendapatkan tekanan dan ancaman untuk bersaksi cenderung memberikan kesaksian palsu dalam perkara pidana di pengadilan karena seamdainya seseorang saksi memberikan kesaksian dengan jujur maka ia merasa takut jiwanya terancam.Berdasarkan hal inilah perlunya dilakukan perlindungan bagi saksi yang sangat penting keberadaannya dalam proses peradilan pidana. Kesaksian merupakan salah satu alat bukti yang penting karena saksi merupakan orang yang mendengar, melihat, dan mengalami sendiri tindak pidana.

\section{METODE PENELITIAN}

Metode penelitian ini menggunakan hukum normatif, yaitu kajian berupa perundangundangan, asas hukum, norma, dan lain-lain. Penelitian hukum normatif adalah suatu prosedur penelitian ilmiah untuk menemukan kebenaran berdasarkan logika keilmuan dipandang dari sisi normatifnya (Johny Ibrahim, 2005). Dalam pembahasan skripsi ini metode yang digunakan adalah deskriptif komperatif, yakni menggambarkan dan menganalisis data mengenai perlindungan saksi menurut konsepsi hukum pidana Indonesia dan hukum pidana Islam. Sedangkan metode komperatif adalah membandingkan antara aturan yang ada dalam hukum pidana Indonesia dan hukum pidana Islam mengenai perlindungan saksi korban pada perkara pidana. Pengumpulan data dilakukan dengan studi kepustakaan melalui penelusuran bahan pustaka, yang meliputi bahan hukum primer berupa buku-buku hukum, peraturan perundangundangan,al-Qur'an, al-Hadits dan bahan hukum sekunder berupa jurnal, makalah, kamus hukum, majalah maupun literatur lainnya yang berkaitan dengan masalah perlindungan saksi menurut hukum Pidana Indonesia dan hukum pidana Islam.

Analisis data merupakan hal yang penting dalam suatu penelitian yaitu untuk memberikan jawaban terhadap masalah yang diteliti. Analisis data dalam penelitian ini dilakukan secara kualitatif dengan metode analisis isi yaitu proses memilih, membandingkan, menggabungkan dan memilah berbagai pengertian, selanjutnya semua bahan hukum tersebut dianalisis untuk menjawab permasalahan penelitian.

\section{HASIL DAN PEMBAHASAN}

Menyangkut dengan perlindungan saksi dalam hukum di Indonesia sudah membentuk Lembaga Perlindungan Saksi dan Korban (LPSK) yang memiliki tiga prioritas dalam melaksanakan tugasnya melindungi saksi diantaranya perlindungan fisik, hukum, dan merahasiakan identitas. Dalam melindungi fisik, haruslah dilakukan oleh orang yang mempunyai kemampuan secara fisik, karena yang dilindungi adalah saksi, termasuk juga keluarga saksi, sedangkan melindungi dari hukum LPSK memberikan kenyamanan dan ketenangan saksi dalam memberikan kesaksian pada waktu perkara sedang diproses terkadang saksi merasa tertekan dalam pemberian kesaksian pada waktu proses perkara yang belum diputuskan. Melindungi saksi dalam merahasiakan identitas LPSK merahasiakan semua yang berhubungan dengan identitas saksi dari siapapun guna keselamatan dan kelancaran penyidikan perkara, terkecuali pada waktu dibutuhkan oleh pihak yang berkewajiban memproses perkara dalam mencari kebenaran dalam memutuskan suatu perkara. Lembaga perlindungan Saksi dan Korban dalam melindungi saksi dan korban tidak mengabaikan hak dan kewajiban saksi tersebut. 
Selanjutnya Islam datang untuk menegakkan kemaslahatan umat, dan dapat berwujud untuk perbaikan perilaku, ketentraman sosial dan mencegah berbagai bahaya, maka Islam akan memberikan perlindungan secara penuh kepada siapa saja yang mendapatkan perlakuan yang tidak adil dari siapapun dan akan memberikan hukuman bagi siapapun yang melakukan kesalahan yang melanggar hukum. Hukum Islam mempunyai tujuan utama yaitu untuk menegakkan dan melaksanakan dengan segenap sumber dan kekuasaan yang terorganisasikan sejalan dengan program reformasi yang telah ditunjukkan Islam demi tegaknya kehidupan yang lebih baik bagi umat manusia. Buat kebajikan dan melarang berbuat kemungkaran. Namun di tangan Allah jaulah akibat semua urusan. Lima prinsip dasar agama Islam, yaitu Pertama, hifzud-din yaitu memberikan jaminan kepada umat Islam untuk memelihara agama dan keyakinannya (al-din). Kedua, hifzun-nafs yaitu menjamin hak atas jiwa (nyawa) manusia, untuk tumbuh dan berkembang secara layak. Ketiga hifzul-aql, yaitu adanya suatu jaminan atas kebebasan berkreasi, berbagai aktivitas ilmiah. Dalam hal ini Islam melarang terjadinya perusakan akal dalam bentuk penyiksaan, penggunaan obat-obatan terlarang, minuman keras dan lain-lain. Keempat, hifzun-nasl yaitu merupakan jaminan atas kehidupan privasi setiap individu, perlindungan atas profesi (pekerjaan) jaminan masa depan keturunan dan generasi penerus yang lebih baik dan berkualitas. Kelima, hifzun-mal yaitu dimaksudkan sebagai jaminan atas pemilikan harta benda, properti dan lain-lain.

Diantara kelima prinsip dasar yang sekaligus menjadi pijakan tujuan pidana Islam itu adalah menunjukkan mengenai salah satu keunggulan tujuan pidana Islam dibandingkan dengan tujuan hukum pidana Indonesia. Misalnya dalam soal perlindungan agama dan pekerjaan kadangkala menjadi ancaman para saksi dalam proses kesaksiannya di pengadilan.

Dari segi tujuannya konsep hukum pidana Indonesia dan hukum pidana Islam memiliki persamaan melindungi saksi yaitu berupaya melindungi para saksi dari ancaman baik secara mental, fisik, harta, keluarga mapun hal lain yang sesuai dengan perlindungan manusia secara normal.Persamaan juga terlihat bahwa keterangan saksi merupakan alat bukti yang utama dalam proses peradilan. Dibalik kesamaan tersebut terdapat perbedaan dalam beberapa hal lain baik menyangkut dengan dasar hukum, macam-macam dan syarat-syarat saksi dan lain-lain. Perbedaan tersebut dapat di gambarkan dalam tabel di bawah ini:

Perbedaan konsep perlindungan saksi menurut hukum pidana Indonesia dan hukum pidana Islam dapat dilihat pada tabel dibawah ini:

\begin{tabular}{|c|c|c|}
\hline No & Hukum pidana Indonesia & Hukum Pidana Islam \\
\hline 1 & $\begin{array}{l}\text { Bersumber dari hukum produk manusia } \\
\text { dalam hal ini Undang-Undang RI No, } \\
13 \text { Tahun } 2006 \text { Tentang Perlindungan } \\
\text { Saksi dan Korban }\end{array}$ & $\begin{array}{l}\text { Bersumber dari Al-Qur'an al-Hadits yang } \\
\text { merupakan ciptaan Allah dan bersumber dari } \\
\text { Rasul }\end{array}$ \\
\hline 2 & $\begin{array}{l}\text { Saksi diwajibkan bersumpah, tetapi } \\
\text { hukum positif akan tetap mengambil } \\
\text { keterangan dari seorang saksi yang tidak } \\
\text { mau bersumpah sebelumnya, dalam hal } \\
\text { ini pernyataan tersebut bukan sebuah } \\
\text { s]kesaksian melainkan hanya sebuah } \\
\text { keterangan yang dapat menguatkan } \\
\text { hakim dalam mengambil keputusan. }\end{array}$ & $\begin{array}{l}\text { Saksi juga harus dilakukan sumpah, tetapi } \\
\text { dalam konsep hukum pidana Islam tidak akan } \\
\text { menerima perntayaan saksi jika tidak } \\
\text { dilandasi dengan sumpah walaupun hanya } \\
\text { sebatas keterangan saja. }\end{array}$ \\
\hline 3 & 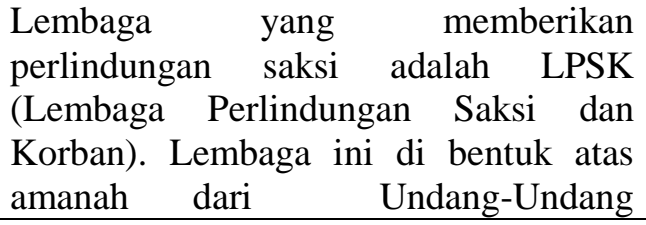 & $\begin{array}{l}\text { Lembaga yang memberikan perlindungan } \\
\text { adalah al-Hisbah yang proses } \\
\text { perlindungannya secara hukum ta'zir } \\
\text { (kewenangan para pemimpin yang memiliki } \\
\text { kewenangan). Dalam hukum ta'zir ini al- }\end{array}$ \\
\hline
\end{tabular}




\begin{tabular}{|l|l|l|}
\hline & $\begin{array}{l}\text { Perlindungan Saksi dan Korban yang } \\
\text { pastinya pelaksanaan merujuk pada asas } \\
\text { legalitas (secara tertulis) atau sesuai } \\
\text { prosedur yang ditetapkan secara tertulis }\end{array}$ & $\begin{array}{l}\text { Qur'an dan al-Hadits hanya mengatur secara } \\
\text { umum saja, pelaksanaanya di berikan pada } \\
\text { pemimpin untuk menjalankan secara } \\
\text { bijaksana demi kemaslahatan umat. }\end{array}$ \\
\hline 4 & $\begin{array}{l}\text { Tidak ditentukan jumlah orang saksi } \\
\text { yang penting ada saksi dalam suatu } \\
\text { perkara pidana }\end{array}$ & $\begin{array}{l}\text { Pada kasus tertentu ditentukan jumlah saksi, } \\
\text { seperti harus ada empat orang saksi laki-laki } \\
\text { adil yang melihat langsung perkara zina itu } \\
\text { terjadi }\end{array}$ \\
\hline 5 & $\begin{array}{l}\text { Tidak diharuskan harus beragama Islam } \\
\text { dalam memeberikan kesaksian, dan para } \\
\text { saksi tersebut disumpah sesuai dengan } \\
\text { agama dan keyakinan masing-masing }\end{array}$ & $\begin{array}{l}\text { Dalam Islam salah satu syarat saksi adalah } \\
\text { muslim, tidak diterima kesaksian dari non } \\
\text { muslim kecuali dalam perkara pidana terjadi } \\
\text { di perjalanan dan tidak ada saksi lain itupun } \\
\text { hanya menyangkut memperjelas duduk } \\
\text { perkaranya saja }\end{array}$ \\
\hline
\end{tabular}

Berdasarkan dua konsep perlindungan saksi diatas, hukum pidana Indonesia sangat mengutamakan keadilan dan kemaslahatan umat. Lembaga perlindungan saksi dalam melaksanakan tugasnya untuk melindungi saksi tidak menyimpang dari apa yang telah di jelaskan dalam ajaran Islam dan sunnah Rasul dimana Islam mengajarkan mengenai manusia memiliki hak al-karamah dan hak al-fadilah dan sunnah Rasul adalah rahmatanlil 'alamin, dimana kemaslahatan / kesejahteraan merupakan tawaran utama-utama seluruh manusia dan alam semesta. Namun, untuk idealnya perlindungan saksi di Indonesia ada baiknya pererintah maupunpihak yang berwenang lainnya dalam membuat aturan hukum memasukkannya secara keseluruhan konsep yang ada dalam hukum pidana Islam ke dalam konsep hukum pidana Indonesia khususnya terhadap perlindungan saksi. Dari persamaan dan perbedaan tersebut kedua sistim hukum diatas, berupaya memberikan rasa aman kepada saksi dalam memberikan keterangan pada persidangan, terutaman menyangkut masalah perlindungan hak asasi manusia.

Penerapan hukum Islam yang benar akan menjamin rasa keadilan bagi manusia.Dalam hukum Islam memelihara agama, jiwa, akal, kehormatan dan harta merupakan hal-hal yang diharuskan bagi manusia, karena hal ini merupakan kebutuhan primer. Islam telah mensyariatkan bagi masing lima perkara itu hukum yang menjamin realisasinya danpemeliharaannya termasuk dalam hal perlindungan saksi.

\section{SIMPULAN}

1. Dalam hukum pidana Indonesia perlindungan saksi bertujuan memberikan rasa aman kepada saksidalam memberikan keterangan pada setiap proses peradilan pidana.. Konsep perlindungan saksi dalam hukum pidana Indonesia berdasarkan pada penghargaan atas harkat dan martabat manusia, rasa aman, keadilan, tidak diskriminatis dan memenuhi asas kepastian hukum. Lembaga Perlindungan Saksi dan Korban (LPSK) mempunyai kewenangan dalam melindungi para saksi dan korban bahwa saksi dan korban memiliki hak untuk dilindungi baik jiwa, harta dan keamanan keluarga saksi dalam memberikan kesaksian pasca perkara yang belum diputuskan oleh hakim. Lembaga perlindungan saksi mempunyai kewenangan dalam melindungi saksi dan korban dalam tiga jenis yaitu : fisik, hukum dan merahasiakan identitas. Untuk yang fisik, harus dilakukan orang yang punya kemampuan secara fisik. Sebab, yang dilindungi ialah saksi dan korban, termasuk keluarganya. Perlindungannya juga sebelum, sidang, dan pasca persidangan.

2. Konsep hukum pidana Islam mengenai perlindungan saksi diberikan jaminan terhadap keselamatan jiwanya yang merupakan tujuan dasar hukum Islam (maqasid al-syari'ah) yaitu perlindungan terhadap agama dan keyakinan, perlindungan atas jiwa, jaminan atas kehidupan privasi setiap individu serta perlindungan atas profesi (pekerjaan) jaminan 
masa depan keturunan dan generasi penerus yang lebih baik dan berkualitas, suatu jaminan atas kebebasan berkreasi, kebebasan membar, kebebasan mengeluarkan opini, dan jaminan perlindungan atas pemilikan harta benda, properti dan lain-lain.

3. Konsep perlindungan saksi dalam hukum pidana Indonesia dan hukum pidana Islam memiliki banyak persamaan yaitu sama-sama melindungi para saksi memiliki upaya pemenuhan pemberian rasa aman kepada saksi sehingga terlepas dari ancaman-ancaman orang lain baik ancaman terhadap jiwa, kehormatan, harta dan keluarga. Namun yang membedakannya terletak pada dasar hukum, syarat dan macam-macam saksi, kekuatan sumpah saksi dan lembaga yang berwenang melakukan perlindungan saksi. Kelebihan konsep erlindungan saksi hukum pidana Islam dibandingkan dengan hukum pidana Indonesia yaitu konsep Islam bukan hanya sekedar untuk melindungi secara dunia saja tapi menyangkut dengan perlindungan secara akhirat tentunya menyangkut dengan perlindungan agama,yang tentunya tidak terdapat dalam hukum pidana Indonesia.

\section{REFERENSI}

Ahmad ad-Daur, dan Terj-Syamsuddin Ramadlan. 2002. Hukum Pembuktian dalam Islam, Bogor: Pustaka Thariqul Izzah.

Andi Hamzah. 1986. Kamus Hukum, Cet. Ke I. Jakarta: Ghalia Indonesia.

Ansharuddin. 2004. Hukum Pembuktian Menurut Hukum Acara Islam dan Hukum Positif, Surabaya, Pustaka Belajar. Departemen Agama RI., al-Qur'an dan Terjemahnya.

Gemala Dewi. 2005. Hukum Acara Perdata Peradilan Agama di Indonesia, Jakarta: Kencana.

Ibnu Mas'ud dan Zainal Abidin. 1999. Fiqih Madzhab Syafi 'i, Bandung: CV. Pustaka Setia.

Imam al-Mawardi. 2006. al-Ahkam as-Sulthoniyyah, Hukum-Hukum Penyelenggaraan Negara dalam Syariat Islam, Penerjemah Fadli Bahri. Cetakan Edisi 2, Jakarta: Darul Falah.

Johny Ibrahim. 2005. Teori dan Metodologi Penelitian Hukum Normatif. Surabaya: Bayu Media Publishing.

Maulana Abu A'la, al-Mawdudiy. 1995. Hak-Hak Asasi Manusia Dalam Islam. Jakarta: Bumi Aksara.

Muhammad Salam Madkur. 1993. Peradilan Dalam Islam, Surabaya: Bina Ilmu.

M. Qurais Shihab. 2000. Tafsir al-Misbah. Jakarta: Lentera Hati.

Ramli Atmasasta. 1997. HAM dan Penegakan Hukum. Bandung: Bina Cipta.

Roihan A Rasyid, Hukum Acara Peradilan Agama, Jakarta: PT. Raja Grafindo Persada

R. Wiyono. 2006. Pengadilan Hak Asasi Manusia di Indonesia, Jakarta: Kencana.

Sudarsono. 2007. Kamus Hukum, Bandung: Rineka Cipta.

Sayyid Sabiq. 1987. Fiqih Sunnah 14, terj. Mudzakir A.S, cet.1. Bandung: Al Ma'arif.

Uwaidah, Syaikh Kamil Muhammad. 2007. Fiqih Wanita. Jakarta: Pustaka Al-Kausar.

Wirjono Projodikoro. 2003. Hukum Acara Pidana Indonesia. Bandung: Sumur.

Yahya Harahap. 2009. Pembahasan Permasalahan dan Penerapan KUHAP, Pemeriksaan Sidang Pengadilan, Banding, Kasasi dan Peninjauan Kembali. Jakarta: Sinar Grafika. 